\title{
Inhaltsübersicht - Band I
}

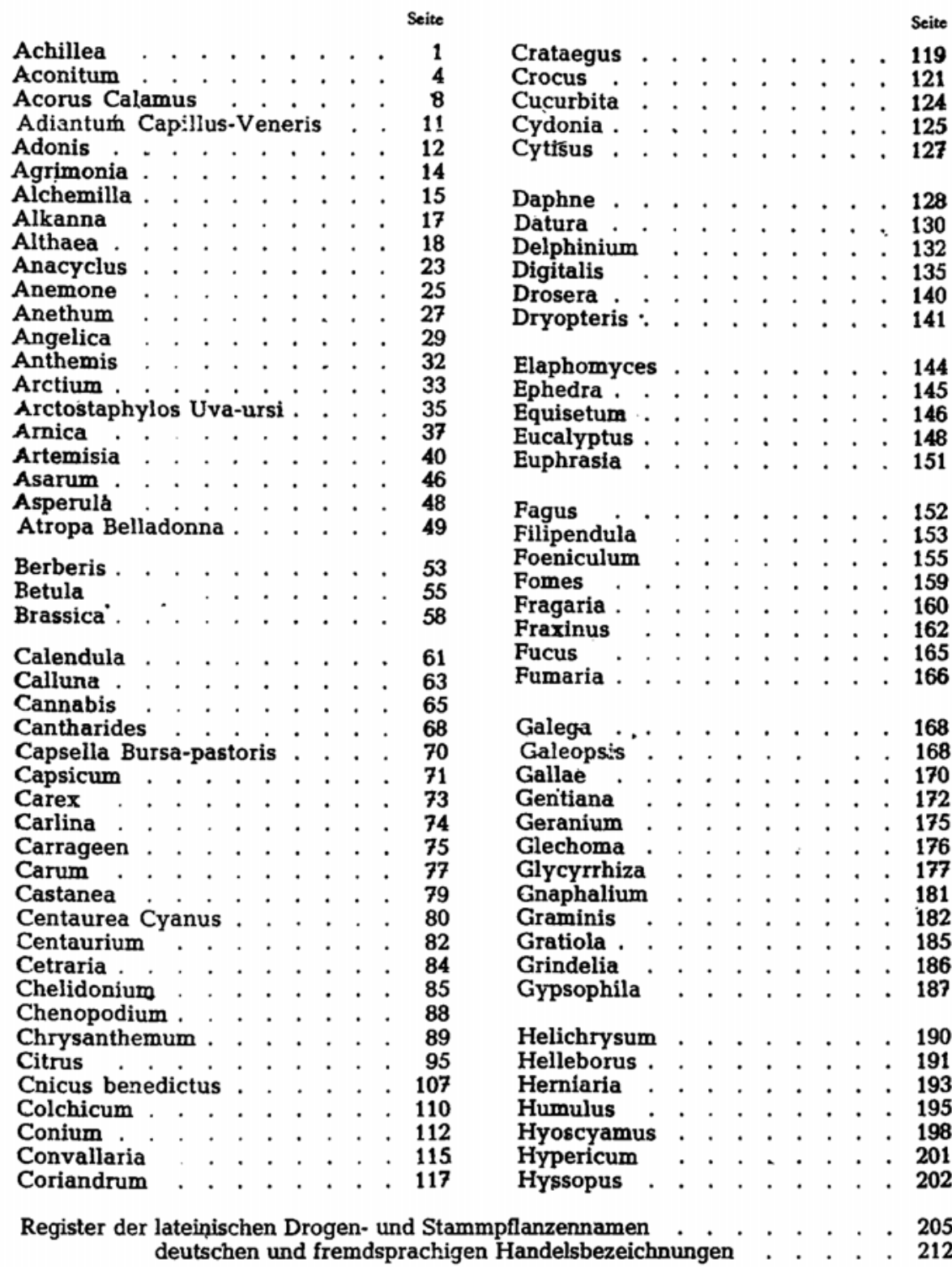

